Goldschmidt 2021 Abstract

https://doi.org/10.7185/gold2021.7924

\section{Contrasted pressure effects on sulfur- oxidizing activity of Thiobacillus thioparus and Thiobacillus denitrificans}

\author{
JORGE R. OSMAN ${ }^{1}$, HERVÉ CARDON ${ }^{2}$, GILLES \\ MONTAGNAC ${ }^{3}$, AUDE PICARD $^{4}$ AND ISABELLE \\ DANIEL $^{5}$
}

${ }^{1}$ Université Lyon 1

${ }^{2}$ Laboratoire de géologie de Lyon UMR 5276, ENS et Université

Lyon 1

${ }^{3}$ Ecole Normale Supérieure de Lyon

${ }^{4}$ University of Nevada

${ }^{5}$ Laboratoire de géologie de Lyon UMR 5276, Université Lyon1

- Ens de Lyon - CNRS

Presenting Author: isabelle.daniel@univ-lyon1.fr

Carbon capture and storage technologies are crucial for reducing carbon emission from power plants as a response to global climate change. The CarbFix project (Iceland) aims at examining the geochemical response of injected $\mathrm{CO}_{2}$ into subsurface reservoirs. After an injection of a fast-flowing $\mathrm{CO}_{2}$ rich fluid in March 2012 that provoked the dissolution of the host-basalt, Trias et al. [1] showed that subsurface groundwater microbial communities indeed reacted quickly to the anthropogenic injection of $\mathrm{CO}_{2}$-rich water. It reduced bacterial diversity and induced the development of iron-oxidizing bacteria, among others. Two months after the injection, under more anaerobic conditions, Thiobacillus species bloomed, suggesting an important role of the latter sulfur-oxidizing bacteria after $\mathrm{CO}_{2}$ injection into basalt. The potential role of the subsurface biosphere has been little investigated up to now in such systems. Here, we used Thiobacillus thioparus and T. denitrificans that likely became abundant at the CarbFix 1 pilot site after injection of $\mathrm{CO}_{2}$ and purified geothermal gases in basaltic aquifer at 400$800 \mathrm{~m}$ depth (4-8 MPa). The capacity of $T$. thioparus and $T$. denitrificans to oxidize thiosulfate was measured by Raman spectroscopy as a function of pressure up to $10 \mathrm{MPa}$. The results show that the growth and metabolic activity of $T$. thioparus are influenced by the initial concentration of the electron donor thiosulfate. It grows best at low initial concentration of thiosulfate and best oxidizes thiosulfate into sulfate at $0.1 \mathrm{MPa}$ with a yield of $14.7 \%$. T. thioparus is piezosensitive and sulfur oxidation stops at 4.3 $\mathrm{MPa}$ [2]. Interestingly, T. denitrificans appears to be piezotolerant up to $8 \mathrm{MPa}$ at least, uses a metabolic pathway for thiosulfate oxidation with tetrathionate as an intermediate, that is different from $T$. thioparus. The metabolic activity of $T$. denitrificans increases and evolves as a function of pressure to $8 \mathrm{MPa}$. These results indicate that autotrophic sulfur oxidizing species can thereby react to the injection of acidic fluids down to $430 \mathrm{~m}$ and $800+\mathrm{m}$ depth and may contribute to induced biogeochemical cycles during subsurface energy operations.

[1] Trias et al., 2017. doi : 10.1038/s41467-017-01288-8
[2] Osman et al. 2021. doi:10.1111/1758-2229.12922 